\title{
The Big Five Personalities as Antecedents of Nurse Performance
}

\author{
Ugung Dwi Ario Wibowo \\ Universitas Muhammadiyah Purwokerto \\ ugungs@yahoo.com
}

\author{
Edwin Setyo Andriyanto \\ Universitas Muhammadiyah Purwokerto \\ edwin.andriyanto93@gmail.com
}

\begin{abstract}
This study was aimed at knowing the effect of personality based on dimensions of the big five personality modelof the nurse performance. This included dimensions such as openness to experience, conscientiousness, extraversion, agreeableness, and neuroticism. The study was a quantitative study using a regression multiple analysis. There were two questionnaires, namely modified big five personality model questionnaire and performance questionnaire. There were 103 nurses as the respondents collected a through purposive sampling technique. The result showed that the performance of the big five model affected the performance of nurses. Also, there were four dimensions in the big five models having the significant effect to the nurse performance. Only agreeableness did not affect significantly to the nurse performance.
\end{abstract}

\section{Keywords: personality, big five model, performance}

\section{INTRODUCTION}

A hospital is one of the institutions engaged in health care providers. The hospital plays an important role in the health system, because the hospital provides complex curative services, emergency services, serves as a referral center, and center for knowledge-technology transfer. Today the success services of a hospital is largely determined by the knowledge, skills, creativity and motivation of the medical employees and nurses [1].

Nursing care in hospitals views nursing as a humanistic service or professional care that use a holistic approach, the services provided must be able to meet the needs of patients as a whole that is biopsychosociocultural and spiritual aspects are done based on the science and tips of nursing and refer to the professional standards of nursing, as well as using nursing ethics as the main demands [2].

In fact, there are some obstacles that may affect the fulfillment of nursing care standards and may also affect the performance of the nurse him/herself. [3] It is reported the case of hospital patient Purwokerto named Sutinah aged 34 years old and her baby which was reportedly died under the suspicion of nurse mistreatment when giving nursing care in the post-birth care and slowness in handling the patient. The hospital, through the head of the public relation department, acknowledged that there was frequent inappropriate communication amongthe family, the patient, and the nurses, he stated that the hospital would improve the quality of service and performance of the nurses. According to this case, it is proven that the performance of nurses still needs many improvements, ranging from priority handling, to the attitudes of the nurses when giving nursing care. The case became a bad precedent for the hospital as this hospital belongs to the provincial government, especially the report cards for the nurse performance.

Nurses dominate the number of health workers in the hospital so that it plays an important role because the nurses servethe patientsfor 24 hours serving [4]. The nurse performance gives a contribution of approximately $40-60 \%$ of hospital services. The nursing service reflects the performance of a hospital because the patient will often be in direct contact with the nurses.

In order for the quality of nursing services and nurse performance to meet the expectation, the human resources of the nurse should have productivity, innovation, special skills, adequate quality and satisfactory service. Besides, nurses also need to know the psychological factors that exist in employees such as attitude problems, personality and employee motivation. In the organization, personality is an important thing that affects the work behavior. According to [5] personality is defined as a composite of all the ways in which an individual reacts and interacts with others, or is sometimes defined as an internal organization of the psychological processes and trends of one's behavior.Personality can push towards the desired behavior of nurses. As it is stated through attitudes and has an important meaning in the organizational behavior, employees or nurses in the hospital who has positivity intheir work tend to produce better performance than nurses who are neutral or even have a negative attitude to his work.

The big five model is a simple personality theory and often used to measure a person's personality. There are several personality factors in the big five model, which are used to characterize the personality, i.e. extraversion, emotional stability or neuroticism, agreeableness, conscientiousness, and openness to experience [6].

According to Robbins [7] in addition to providing a single personality framework, research on the big five model has also found an important relationship between personality and performance dimensions at work. Another study conducted by [8] found that big five personality has a significant effect on nurse performance. Nurses in completing their duties are required to work together in a team and have the proper discipline so that 
the employee's personality affects their performance, both individually and in a team. In another research conducted by [9] there is an effectof the big five dimension to performance, but from the five big five dimension there are only two dimensions that effect the performance of civil servants, that is conscientiousness and openness to experience.

Therefore the researcher is interested to know how the personality based on dimensions of the big five model effects the performance of the nurses at Hospital $\mathrm{X}$ in Purwokerto. The purpose of this research is to knowthe effect of personality dimensions based on the big five model simultaneously and partially towards their performance.

Nurses

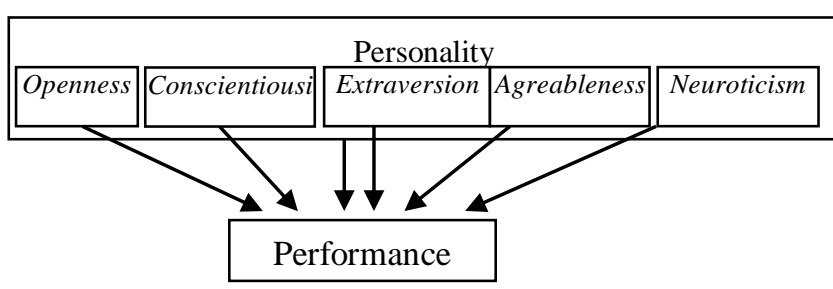

Figure 1. Framework of the research

\section{METHOD}

This research uses causal research as a study design because the purpose of this research to prove a causal relationship between the variables studied [10]. This research is classified as quantitative research that uses statistical procedures or other means of quantification to measure the research variables [11].

The independent variables in this research are personalities, meanwhile, dependent variable in this study is performance. In the process, theresearchers usethe personalities factors in the big five model: extraversion, emotional stability or neuroticsm, agreeableness, conscientiousness, and openness to experience [12] as partially independent variables. The population are 666 nurses of Hospital X, a state hospital inPurwokerto, Central Java, Indonesia. The research usespurposive sampling method, while the number of samples in this study are 103 respondents. The samples are taken according to these characteristics: (a) nurses working in Hospital X Purwokertofor at least one year; and (b) working in inpatient installations. The reason to use nurse samples that work in inpatient installation is that the number of nurses on the installation is relatively morethan that in other divisions and these nurses have a higher intensity to perform services to the in-patients.

The data collection technique uses the questionnaire. Researchers used data retrieval method with a scale, which is a design study that asks others express/respond about themselves in the range of options [13].

To test the hypothesis researchers use multiple regression analysis. And, in the process of data calculations, the researchers use the program SPSS for Windows Release 22.00

\section{RESULT}

Multiple regression analysis is used to find out the effect of some independent variables on dependent variables and can also be used to know personality contribution based on the big five model on nurse performance. In the regression, there are three things to note [11]. First, the number of R-square (R2) to find out the percentage $(\%)$ of the dependent variable variance described by the independent variables. Secondly, the overall independent variableswhich have a significant effect on the dependent variables. And the third, attention to the significance of the regression coefficient of each independent variable.

The number of $\mathrm{R}$-square to find out the dependent variable variance is explained by the independent variable such as .749; it can be interpreted that the proportion of variance of the performance variables described by all dimensions of openness to experience, conscientiousness, extraversion, agreeableness, and neurotics is $25.1 \%$; this is influenced by other variables beyond this study.

Then the researchersperform the $F_{\text {test }}$ to analyze the effect of all free variables or dimensions in the big five model. The $F_{\text {test }}$ results reveal that the value of $F(57.835)$ $>\mathrm{F}_{\text {table }}(2.30)$ and $\mathrm{p}$ (Sig.) has a value of .000 with a value of $\mathrm{p}<.05$. Thus it can be interpreted that $(\mathrm{Ho})$ is rejected, which states there is no significant effect of all independent variables on the performance. In other words, there is a very significant simultaneouseffect of openness to experience, conscientiousness, extraversion, agreeableness, and neuroticsm onnurse performance.

The last step, which is seen in the regression coefficient of each independent variable from the big five model dimensionscan be viewed from the Table.1.

Table 1. Coefficients ${ }^{\mathrm{a}}$

\begin{tabular}{|c|c|c|c|c|c|}
\hline \multirow{2}{*}{ Model } & \multicolumn{2}{|c|}{$\begin{array}{l}\text { Unstandardize } \\
\text { d Coefficients }\end{array}$} & \multirow{2}{*}{$\begin{array}{c}\begin{array}{c}\text { Stand. } \\
\text { Coef. }\end{array} \\
\text { Beta }\end{array}$} & \multirow{2}{*}{$\mathbf{T}$} & \multirow{2}{*}{ Sig. } \\
\hline & B & $\begin{array}{c}\text { Std. } \\
\text { Error }\end{array}$ & & & \\
\hline (Constant) & 31.534 & $\begin{array}{r}14.36 \\
1 \\
\end{array}$ & & 2.196 & .030 \\
\hline Openness & .868 & .250 & .240 & 3.478 & .001 \\
\hline $\begin{array}{l}\text { Conscientiou } \\
\text { sness }\end{array}$ & .593 & .226 & .230 & 2.617 & .010 \\
\hline Extraversion & 1.016 & .198 & .387 & 5.128 & .000 \\
\hline $\begin{array}{l}\text { Agreeablene } \\
\text { Ss }\end{array}$ & .161 & .194 & .072 & .829 & .409 \\
\hline Neuroticism & -.424 & .186 & -.130 & -2.281 & .025 \\
\hline $\begin{array}{l}\text { a. Dependen } \\
\text { Based on the } \\
\text { equation is as fol } \\
Y \text { (Performa } \\
X 2 \text { (conscientiou } \\
\text { (agreeableness) } \\
\text { Then it can } \\
\text { coefficients ab } \\
\text { openness to ex }\end{array}$ & $\begin{array}{l}\text { Variable: } \\
\text { table above } \\
\text { lows: } \\
\text { (ce) }=31,5 \\
\text { sness) }+1 \\
0,424 X 5 \\
\text { be obser } \\
\text { ove, only }\end{array}$ & $\begin{array}{l}\text { Performo } \\
\text { e, it is ex } \\
534+0,8 \\
, 016 \times 3 \\
\text { (neurotici } \\
\text { ved from } \\
y \text { the re }\end{array}$ & $\begin{array}{l}\text { ance } \\
\text { plained th } \\
68 \times 1 \text { (o } \\
\text { (extraver } \\
\text { ism) } \\
\text { the tab } \\
\text { gression }\end{array}$ & $\begin{array}{l}\text { at the res } \\
\text { enness) } \\
\text { ion) }+0 \\
\text { e of reg } \\
\text { coeffic }\end{array}$ & $\begin{array}{l}\text { ression } \\
+0,593 \\
161 X 4 \\
\text { ression }\end{array}$ \\
\hline
\end{tabular}


Meanwhile the regression coefficient of agreeableness is not significant because in the agreeableness dimension obtained $\mathrm{t}_{\text {-value }}$ is $.829<\mathrm{t}_{\text {table }}(1.988)$, and regression coefficient value is equal to .161 with significance .409 (Sig. > .05). This means that out of the five minor hypotheses, only four are received.

\section{DISCUSSION}

From the results of research and hypothesis testing, it can be concluded that in the personality based on big five model, there is a significant influence on the nurse performance of Hospital X Purwokerto. This research is supported by twostudies, conducted by [14] which states that there is a significant influence of the big five personality to the performance. Moreover, the study by [15] examines the big five model personality dimensions on five different criteria and types of work; the findings suggest that the dimensions of openness to experience influence learning and training, the conscientiousness dimension has an influence on all types of work, the extraversion dimension is capable of affecting performance on the job of providing training, the dimension of agreeableness has an influence on police officers and managers, and the dimensions of neuroticism have an influence on police officer performance.

Then according to [16], one of the determinants of performance result is the personality of how attitude and behavior have a pleasant impression to support the performance of employees.

In the regression coefficient analysis, only four dimensions significantly affect the performance of the nurses: the openness to experience, conscientiousness, extraversion, and neuroticism. Meanwhile, the dimension of agreeableness has no significant effect on the performance of the nurses. From the results of these studies there are suitability as well as differences with theories that have also examined these variables before.

From the big five model dimensions in this study, the first dimension that significantly affects the performance of nurses Hospital X Purwokerto is the dimension of openness to experience. This dimension is illustrated by Costa \& McCrae in [17], as a person with curiosity, broad interests, creative, original, imaginative, and not traditional. Dollinger and Orf [18] in his research dimension say that openness to experience is a very influential predictor of performance.

Based on personality research of the big five model,the dimension of agreeablenessdoes not significantly affect the performance of nurses, but that dimension contributes to the performance of .501.According to Costa \& McCrae [19],agreeablenesscan be illustrated in assessing the quality of individual orientation with the continuum ranging from gentle to antagonistic in thinking, feeling and behavior. This is in accordance with research conducted by [20] that agreeableness does not support the performance, on civil servants in BKD of Central Java Province.
Thus, this study is also in line with findings in research conducted by [21], which found that the results for agreeableness is not an important factor in supporting performance, although in jobs that intersect with the social environment. In contrast, in the findings of Barrick\& Mount's it was found that the extraversion dimension has an impact on performance. So it can be illustrated that the personality of agreeableness is personally polite, gentle and trusting has no impact on performance instead of the extraversion personality illustrated with personal activeness, including the activeness in speaking, as well as a firm personality that has an impact on performance.

\section{CONCLUSION}

Based on findings and discussions, the conclusion of this researchisthe big five model personality has significantly affects the nurse performance. Yet, there areonly four of five dimensions in the big five model that have the significantly effect to thenurse performance. The dimension of agreeableness does not significantly affect the nurse performance.

\section{REFERENCES}

[1] R.N., Indahsari and U.D.A, Wibowo. "Pengaruh Kualitas Pelayanan terhadap Kepuasan pada Pasien Rawat Inap Jamkesmas di RSUD Banyumas", Psycho Idea, vol. 11, no. 2, pp. 5663, 2013

[2] Bidang Perawatan RSMS, "Pedoman Pelayanan Keperawatan RSUD Prof. Dr. Margono Soekarjo Purwokerto",unpublished, Purwokerto, 2015

[3] http://www.antaranews.com/berita/572625/ibudan-bayi-meninggal-keluarga-adukan-rsud.

[4] D. Fitrianasari, N. Umar,and HN Utami, "Pengaruh Kompensasi dan Kepuasan Kerja Terhadap Organizational Citizenship Behavior (OCB) dan Kinerja Karyawan",Jurnal Profit,vol 7,no.1, pp 12-24, 2013

[5] M. Muchlas, "Perilaku Organisasi", Gadjah Mada University Press, Yogyakarta, 2015

[6] J.L.Gibson, J.M, Ivancevich, J.H, Donnelly, and R. Konopaske, "Organizations: Behavior, Structure and Process", 2006.

[7] S.P, Robbins and T.A. Judge, "Perilaku Organisasi"(translated by Diana Angelica, etc), Salemba Empat, Jakarta, 2008

[8] D.Natalia, and V, Agustini, "Analisis Pengaruh The Big Five Personality terhadap Organizational Citizenship Behavior (OCB) dan Kinerja Perawat di RS Santa Clara Madiun",Jurnal Manajemen Indonesia, Vol. 15 No. 1, pp 51-64. 2015.

[9] H, Widhiastuti, "The Big Five Personalitysebagai Penunjang Kinerja Studi kasus pada Pegawai Negeri Sipil (PNS)",Jurnal Asvattha, vol. 1 no. 4, 2011. 
[10] Sugiyono, "Statistika untuk Penelitian", Alfateta, Bandung, 2006

[11] S. Hadi,"Metodologi Reasearch II" Yayasan Penerbit Psikologi UGM, Yogyakarta, 2000.

[12] P. Jewell and R. Siegell,"Psikologi Industri/Organisasi Modern", (translated by: A, Hadyana Pudjaatmaka dan Meitasari),Penerbit Arcan, Jakarta, 1998.

[13] Hasibuan, "Manajemen Sumber Daya Manusia", Bumi Aksara, Jakarta, 2008.

[14] Barrick Murray R, Mount Michael K,"The Big Five Personality Dimensions and Job Performance: A Meta-Analysis", Departement of Management and Organizations Univerity of Lowa, 1991.
[15] L.A. Pervin, Cervone, Daniel., and P.J. Oliver, "Psikologi Kepribadian: Teori dan Penelitian". Kencana Prenada Media Group, Jakarta, 2012.

[16] J.Salgado, "The Five Factor Model of Personality and Job Performance in the European Community", Journal of Applied Psychology, https://www.researchgate.net/ publication/ 14098123, 2014.

[17] W. Dyahrini, "Pengaruh Kepribadian Karyawan Terhadap Kinerja Karyawan Akdemik Menurut Teori The Big Five pada Universirtas Widyatama Bandung”, Skripsi, 2008. 